\title{
Variation of salts and available nutrients in salt- affected soil during leaching process under the influence of organic ameliorators
}

Jie Wang, Guodong Yuan, Jian Lu, Jun Wu \& Jing Wei

To cite this article: Jie Wang, Guodong Yuan, Jian Lu, Jun Wu \& Jing Wei (2019): Variation of salts and available nutrients in salt-affected soil during leaching process under the influence of organic ameliorators, Chemistry and Ecology, DOI: 10.1080/02757540.2019.1702977

To link to this article: https://doi.org/10.1080/02757540.2019.1702977

\section{曲 Published online: 13 Dec 2019.}

Submit your article to this journal $\widetilde{1}$

\section{Џll Article views: 4}

\section{Q View related articles $₫$}

\section{View Crossmark data ¿}




\section{Variation of salts and available nutrients in salt-affected soil during leaching process under the influence of organic ameliorators}

Jie Wang ${ }^{\mathrm{a}, \mathrm{b}}$, Guodong Yuan ${ }^{\mathrm{a}, \mathrm{c}}$, Jian $\mathrm{Lu}^{\mathrm{a}, \mathrm{b}}$, Jun Wu $\mathrm{W}^{\mathrm{d}}$ and Jing Wei ${ }^{\mathrm{a}}$

${ }^{a}$ CAS Key Laboratory of Coastal Environmental Processes and Ecological Remediation, Yantai Institute of Coastal Zone Research (YIC), Chinese Academy of Sciences (CAS); Shandong Key Laboratory of Coastal Environmental Processes, YICCAS, Yantai, People's Republic of China; ${ }^{b}$ University of Chinese Academy of Sciences, Beijing, People's Republic of China; 'School of Environmental and Chemical Engineering, Zhaoqing University, Zhaoqing, People's Republic of China; ${ }^{d}$ School of Resources and Environmental Engineering, Ludong University, Yantai, People's Republic of China

\begin{abstract}
This study investigated the potential influence of three organic ameliorators (peat, biochar and leonardite) on salts and nutrients in salt-affected soils during intermittent leaching. Results showed that nearly $90 \%$ of salt was removed from columns in the leaching process and sodium adsorption ratio (SAR) of the soil after leaching was reduced by $67.3 \%$ (control, CK), $62.9 \%$ (peat), $70.1 \%$ (biochar) and $55.0 \%$ (leonardite). Total $\mathrm{N}$ loss declined by $26.2 \%$ (peat), $11.7 \%$ (biochar) and $55.5 \%$ (leonardite) compared with CK in the process of leaching. The maintaining $\mathrm{N}\left(\mathrm{NH}_{4}^{+}\right.$and $\left.\mathrm{NO}_{3}^{-}\right)$of soil after leaching was $8.25,7.31,11.31$ and $14.48 \mathrm{mg} / \mathrm{kg}$ for $\mathrm{CK}$, peat, biochar and leonardite treatments. Final P loss was $0.47,0.31,0.54$, $0.27 \mathrm{mg} /$ column in leaching for CK, peat, biochar and leonardite treatments. Soluble P of soil after leaching was measured as 6.95 (CK), 5.62 (peat), 8.52 (biochar) and 3.33 (leonardite) mg/kg. Leaching could remove the salt effectively but with nutrient loss in the process. The findings of this study suggest that organic ameliorators (biochar, peat or leonardite) play an important role in retaining nutrients during leaching as well as supplying nutrients after leaching to offer practical assistance for the amendment of salt-affected soil in the Yellow River Delta.
\end{abstract}

\section{ARTICLE HISTORY}

Received 21 June 2019

Final Version Received 5

December 2019

\section{KEYWORDS}

Amelioration of salt-affected soils; salt leaching; biochar; leonardite; peat

\section{Introduction}

Salt-affected soils (i.e. saline and sodic), known as a series of soils affected by saline-alkali components, include various saline and alkali soils as well as other soils with varying degrees of salinisation and alkalisation [1]. Salt-affected soils are widely distributed in global arid and semi-arid regions. In recent years, salt-affected soils have been expanding with more serious salinisation due to both natural (such as global climate change and seawater intrusion) and anthropic reasons (e.g. unreasonable irrigation and overuse of inorganic fertilisers) [2,3]. Low organic matter and nutrients, insufficient fertiliser supply 
capacity and excessive salts in saline soils have caused physiological drought of crops, which affects the absorption and utilisation of nutrients to further result in yield reduction, quality decline and even sterilisation [4-6].

Many methods including engineering (underground drainage, physical barrier, etc.), chemical amelioration and biological restoration have been applied to amend the saltaffected soil [7-9]. The main idea of most practical measures is to reduce salt accumulation around roots, which results in a large demand for freshwater [10]. However, the feasible alternatives for amending saline soil are limited for areas with scarce water resources.

The biochar is the product of thermal decomposition of biowastes under limited/no oxygen and temperature ranging from 300 to $1000^{\circ} \mathrm{C}$ [11]. Many pots and field experiments demonstrate that the biochar plays an important role in improving soil structure and promoting soil fertility and plant growth by its porous structure, large cation exchange capacity (CEC), abundant oxygen-containing functional groups and nutrients $[12,13]$. Unlike biochar produced by intense combustion, the peat and leonardite are more like the residuals of slow combustion. The peat is usually formed by the transformation and accumulation of dead plant residues in marshes [14], while leonardite is a kind of oxidised shallow coal [15]. Both of them have the characteristics of huge CEC (cation exchange capacity), good ventilation and permeability, high humic acid content, strong adsorption and chelating ability, and excellent salt balance control ability [16]. Moreover, the peat and leonardite can help crops resist drought and salinity hazards.

Being one of the three major estuary deltas in China, the Yellow River Delta that is located on the west coast of the Bohai Sea has become one of the key development areas of Shandong Blue Economic Circle Strategy. This area with abundant reserve land resources exhibits low land use rate due to the serious salinisation. In addition, water resources in this area are scarce. It is not feasible to amend saline farmlands by flushing soils with large amount of water. Therefore, it is necessary and urgent to find economical, effective and sustainable method for reducing soil salinity or adjusting components of saline soils in the Yellow River Delta. Low content of organic matter is regarded as one of the main reasons to restrict the productivity of saline soil. Organic amendments can not only improve soil properties but also increase soil fertility, especially suitable for arid and semi-arid areas [17]. Thus the purpose of this study is to compare the effects of different organic amendments (peat, biochar and leonardite) on leaching of salts and nutrients in salt-affected soils.

\section{Materials and methods}

\subsection{Study area and sampling}

The field site is adjacent to the Bohai Sea and located in the Yellow River Delta ( $\mathrm{N} 37^{\circ}$ $41^{\prime} 17.25^{\prime \prime}, \mathrm{E} 118^{\circ} 36^{\prime} 03.76^{\prime \prime}$ ), China. Mean annual precipitation here is $564 \mathrm{~mm}$, however, approximately $78 \%$ of the precipitation occurs from June to September [18]. Top saltaffected soil samples with depth of $20 \mathrm{~cm}$ were obtained from tilled land in November 2016 after winter wheat sowing. The texture of soil was clay loam with salt content of $7.5 \%$ and bulk density of $1.25 \mathrm{~g} / \mathrm{cm}^{3}$. The organic matter and total nitrogen content of target soil were 9.84 and $1.23 \mathrm{~g} / \mathrm{kg}$, respectively. The soil samples were crushed to pass through the $1 \mathrm{~mm}$ sieve after natural air-drying in the laboratory. 
Three carbon-rich ameliorators were used in this study, including leonardite (Luliang, Shanxi), peat (Jiahe Company, Heilongjiang) and biochar (produced by corncob at $400^{\circ}$ C with oxygen limitation). The CEC of leonardite/peat/biochar was 53.15/134.76/ $75.97 \mathrm{cmol} / \mathrm{kg}$, and other properties were presented in Table 1. Ameliorators were sieved through $0.15 \mathrm{~mm}$ sieve and dried at $40^{\circ} \mathrm{C}$ for reserve prior to the experiment.

\subsection{Experiment design}

Leaching columns used in this experiment were made of polypropylene with an internal diameter of $5 \mathrm{~cm}$. The cylinders were filled with clean gauze at the bottom to prevent soil flowing by. Leachate from each column was collected in $100 \mathrm{~mL}$ polyethylene bottle which was weighed before leachate collection in order to determine the leachate volume. The weight of leachate was the weight difference of empty bottle and bottle containing leachate. The leachate volume could be calculated using leachate weight and its supposed density of $1.0 \mathrm{~g} / \mathrm{cm}^{3}$.

All columns were packed to the bulk density of $1.25 \mathrm{~g} / \mathrm{cm}^{3}$ according to the field measurement. Before filling columns, ameliorator was mixed fully with soil to reach the final content of $30 \mathrm{~g} / \mathrm{kg}$. Each treatment had three replicates. A hole was drilled at the end caps and drain tubes were attached to the bottom of each column by a rubber. Every $5 \mathrm{~cm}$ soil was compacted to form a $15-\mathrm{cm}$ soil column. Deioned (DI) water was used to simulate the rainfall. Volume of each leaching event was determined as $50 \mathrm{~mL}$ according to the heavy rain event in summer. Each leaching was dripped drop by drop, and accomplished within $24 \mathrm{~h}$ for every 3 days. A petri dish was put on the top of column to prevent the evaporation of water from the column during the interval. The experiment completed after six leaching events.

Soils in the columns after leaching were air dried and passed through $2 \mathrm{~mm}$ sieve. Physiochemical properties including EC (electrical conductivity), $\mathrm{pH}$ and soluble ions $\left(\mathrm{Na}^{+}, \mathrm{K}^{+}\right.$, $\mathrm{Ca}^{2+}$ and $\mathrm{Mg}^{2+}$ ) concentration as well as nutrients (soluble $\mathrm{NH}_{4}-\mathrm{N}, \mathrm{NO}_{3}-\mathrm{N}$ and $\mathrm{PO}_{4}^{3-}$ ) were determined. SAR (sodium adsorption ratio) was calculated.

\subsection{Analysis method}

Soluble salt content of the soil was determined by the residual drying method, CEC was determined using a sodium acetate - flame photometry method and total cation mass

Table 1. Chemical compositions and basic properties of ameliorators and soil.

\begin{tabular}{|c|c|c|c|c|c|c|c|c|c|c|c|}
\hline \multirow[b]{2}{*}{ Water extracts } & \multirow[b]{2}{*}{$\mathrm{pH}$} & \multirow[b]{2}{*}{$\mathrm{EC}(\mathrm{mS} / \mathrm{cm})$} & $\mathrm{Na}^{+}$ & $\mathrm{K}^{+}$ & $\mathrm{Ca}^{2+}$ & $\mathrm{Mg}^{2+}$ & $\mathrm{NH}_{4}^{+}-\mathrm{N}$ & $\mathrm{NO}_{3}-\mathrm{N}$ & $\mathrm{PO}_{4}^{3-}$ & & \\
\hline & & & \multicolumn{4}{|c|}{$(\mathrm{g} / \mathrm{kg})$} & \multicolumn{3}{|c|}{$(\mathrm{mg} / \mathrm{kg})$} & & \\
\hline Peat & 4.57 & 1.70 & 0.27 & 0.07 & 0.97 & 0.47 & 0.33 & 1.23 & 0.11 & & \\
\hline Biochar & 7.99 & 8.32 & 2.00 & 6.83 & 0.21 & 0.20 & 0.06 & 0.08 & 12.12 & & \\
\hline Leonardite & 4.87 & 1.33 & 0.11 & 0.01 & 0.94 & 0.17 & 57.65 & 30.64 & 0.57 & & \\
\hline Soil & 7.56 & 3.04 & 2.09 & 0.04 & 0.39 & 0.17 & 1.87 & 30.12 & 7.03 & & \\
\hline \multirow[t]{2}{*}{ Amendments } & $\mathrm{Na}^{+}$ & $\mathrm{K}^{+}$ & $\mathrm{Ca}^{2+}$ & $\mathrm{Mg}^{2+}$ & $-\mathrm{COOH}$ & $-\mathrm{OH}$ & Ash & C & $\mathrm{N}$ & $\mathrm{H}$ & $S$ \\
\hline & \multicolumn{4}{|c|}{$(g / k g)$} & \multicolumn{2}{|c|}{ (mol/kg) } & \multicolumn{5}{|c|}{ (\%) } \\
\hline Peat & 2.01 & 2.99 & 3.69 & 2.57 & 0.72 & 1.71 & 18.00 & 49.73 & 2.56 & 0.07 & 0.66 \\
\hline Biochar & 7.81 & 18.84 & 19.00 & 5.38 & 1.85 & 1.63 & 64.02 & 46.92 & 0.56 & 3.07 & 0.14 \\
\hline Leonardite & 1.66 & 1.07 & 19.87 & 1.60 & 2.74 & 1.63 & 25.70 & 43.17 & 0.87 & 2.74 & 1.24 \\
\hline
\end{tabular}


was determined by $\mathrm{HNO}_{3}-\mathrm{HClO}_{4}-\mathrm{HF}$ method [19]. Soluble cations $\left(\mathrm{Na}^{+}, \mathrm{Ca}^{2+}, \mathrm{Mg}^{2+}\right.$ and $\left.\mathrm{K}^{+}\right)$ were analysed by ion chromatography Dionex ICS3000 (Dionex Corporation, USA). Soluble $\mathrm{NH}_{4}-\mathrm{N}, \mathrm{NO}_{3}-\mathrm{N}$ and $\mathrm{PO}_{4}^{3-}$ was determined by continuous flowing analyser (Seal-Branlubbe $\mathrm{AA} 3$, Germany). The contents of $-\mathrm{COOH}$ and phenol $-\mathrm{OH}$ were determined through the titration method provided by the International Humic Substances Society (http://humicsubstances.org/). Soil organic carbon was determined by wet digestion using a mixture of potassium dichromate and sulphuric acid, followed by heating [20]. Electric conductivity (EC) and $\mathrm{pH}$ were measured at the soil-liquid ratio of 1:5. Inorganic and total organic carbon were determined by total organic carbon analyser (Shimadu TOC VCPH, Japan).

\subsection{Data analysis}

Data were analysed by Origin 8.1, Excel 2003 and SPSS 19.0. Duncan's multiple comparison test $(P<0.05)$ was conducted to determine the difference of means for the soil analysis results. SAR was calculated by the following equation [21]:

$$
\mathrm{SAR}=\frac{\left[\mathrm{Na}^{+}\right]}{\sqrt{\left[\mathrm{Ca}^{2+}\right]+\left[\mathrm{Mg}^{2+}\right]}},
$$

where $\left[\mathrm{Na}^{+}\right],\left[\mathrm{Ca}^{2+}\right]$ and $\left[\mathrm{Mg}^{2+}\right]$ in solution were expressed in $\mathrm{mmol} / \mathrm{L}$.

$$
\text { Cumulative leachate of cations }=\sum_{i=1}^{n=6} C_{i} * V_{i},
$$

where $C_{i}(\mathrm{mmol} / \mathrm{L})$ and $V_{i}(\mathrm{~L})$ shown in Equation (2) denoted the amount of relative cation in leachate corresponding to the leaching event (e.g. when $i=2$, it is referred as the second leaching event).

\section{Results and discussion}

\subsection{Basic properties of ameliorators and the soil}

$\mathrm{Na}^{+}$was the main cation in soil extract before the experiment to account for more than $80 \%$ of total cations $\left(\mathrm{Na}^{+}, \mathrm{K}^{+}, \mathrm{Ca}^{2+}\right.$ and $\mathrm{Mg}^{2+}$ ) while by $\mathrm{Ca}^{2+}$ accounted for $8.9 \%$ of total cations (Table 1). SAR of soil extract was also high due to the high concentration of soluble $\mathrm{Na}^{+}$.

The background properties of raw materials played important role in soil amendment. Hydroxyl and carboxyl groups with high contents enabled the three carbon-rich ameliorators to possess strong ion exchange and complexation ability, and a certain amount of nitrogen or phosphorus demonstrated the potential of providing nutrients. Biochar was alkaline with $\mathrm{pH}$ of 7.99 while peat/leonardite was acidic with $\mathrm{pH}$ of 4.51/4.87 in the presence of humic substance (Table 1). Monovalent $\mathrm{K}^{+}$in biochar was relatively abundant in comparison with cations and soluble $\mathrm{K}^{+}$even reached $6.83 \mathrm{~g} / \mathrm{kg}$, which could not only supply nutrient but also help resist salt damage of crops [22,23]. Divalent ions including $\mathrm{Ca}^{2+}$ and $\mathrm{Mg}^{2+}$ were dominant in peat and leonardite. Soluble $\mathrm{Ca}^{2+}$ in leonardite was up to $0.94 \mathrm{~g} / \mathrm{kg}$, and the total amount of $\mathrm{Ca}^{2+}$ was $19.87 \mathrm{~g} / \mathrm{kg}$. It is generally believed that $\mathrm{Ca}^{2+}$ could contribute to the improvement of salt-affected soil by displacing exchangeable $\mathrm{Na}^{+}$which is the basis of gypsum as an amendment [24], promoting the 
formation of aggregate structure [25], and improving the physical and chemical properties of saline soil.

\subsection{Variation of physiochemical properties of soil and leachate during and after leaching}

The leachate $\mathrm{pH}$ of each group varied with two significant stages during the leaching process (Figure 1a). The leachate pH slowly declined to the bottom (around 7.8) at the third leaching event with leachate volume of $150 \mathrm{~mL}$, and then soared up to 9.1 with increasing amount of inorganic carbonate. The concentration of inorganic carbon $\left(\mathrm{HCO}_{3}^{-}\right.$and $\left.\mathrm{CO}_{3}^{2-}\right)$ in the leachate of control $(\mathrm{CK})$, biochar treatment, peat treatment and leonardite treatment was less than $50 \mathrm{mg} / \mathrm{L}$ at the beginning and 216.9, 247.8, 333.3 and $420.3 \mathrm{mg} / \mathrm{L}$ at the end of leaching with $p<0.05$, respectively (Figure $1 \mathrm{~b}$ ). A preliminary conclusion was obtained that the rapid increase in $\mathrm{pH}$ during the leaching process was possibly caused by the production of inorganic carbon if considering the existence of inorganic carbon in leachate. Alkalisation during the desalination process of saline soils had
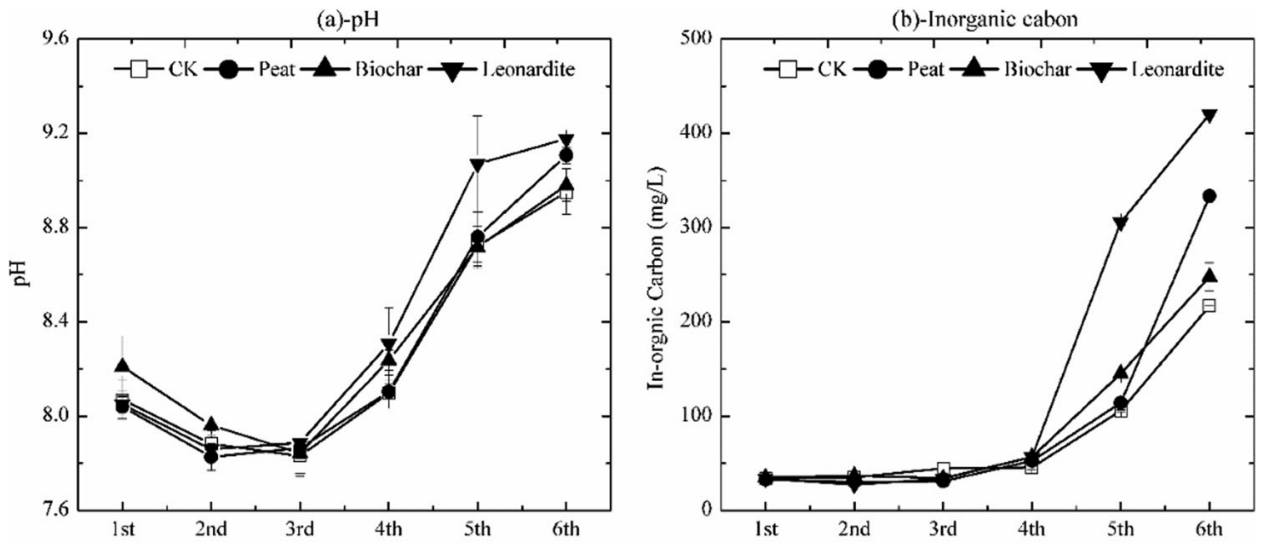

(c)-EC
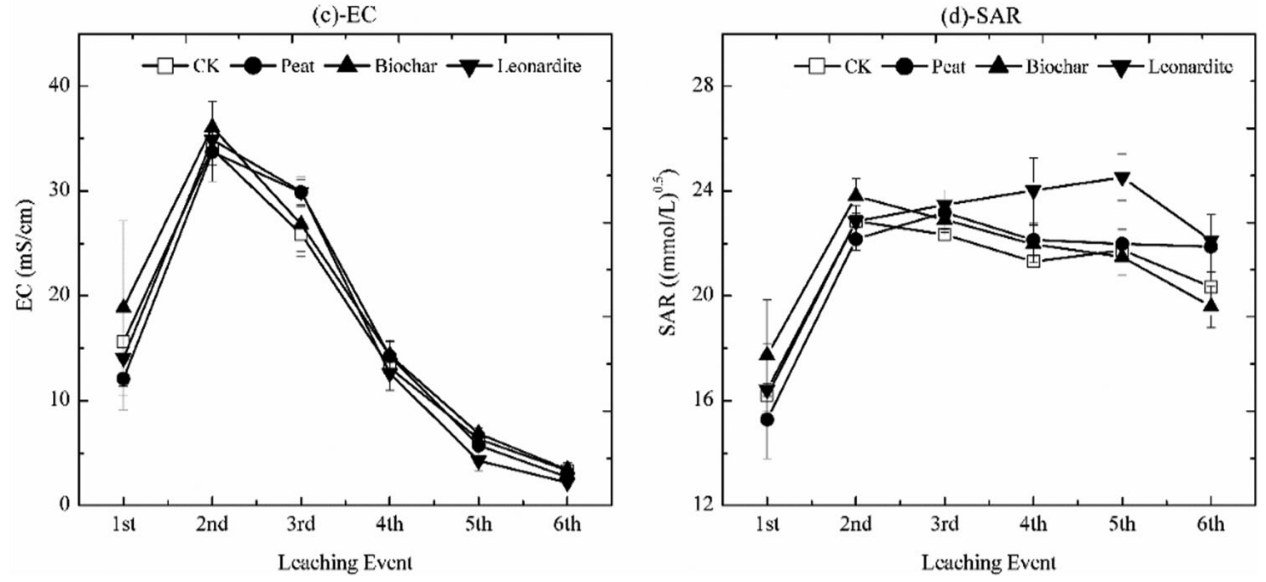

Figure 1. Variation of leachate $\mathrm{pH}, \mathrm{IC}, \mathrm{EC}$ and SAR in the process of leaching. (a: $\mathrm{pH}$ variation of different treatments; b: inorganic carbon content variation of different treatment; $c$ : EC variation of different treatments; d: SAR variation of different treatments). 
been observed in many leaching experiments [26,27], which might be related to the equilibrium of $\mathrm{CaCO}_{3}$ precipitation and dissolution, i.e. $\mathrm{CaCO}_{3}+\mathrm{CO}_{2}+\mathrm{H}_{2} \mathrm{O} \leftrightarrow \mathrm{Ca}^{2+}+2 \mathrm{HCO}_{3}^{-}$ $[28,29]$. Carbonate minerals dissociated to produce $\mathrm{HCO}_{3}^{-}$and $\mathrm{CO}_{3}^{2-}$ in order to balance the charge in the soil when anions such as $\mathrm{Cl}^{-}$and $\mathrm{SO}_{4}^{2-}$ were leached out of soil. More $\mathrm{HCO}_{3}^{-}$and $\mathrm{CO}_{3}^{2-}$ were needed when other anions gradually decreased with the leaching process. Peat and leonardite were obviously acidic to activate calcium carbonate in soil and promote $\mathrm{CaCO}_{3}$ hydrolysis to form more $\mathrm{Ca}^{2+}$ and $\mathrm{CO}_{3}^{2-}$ to some extent, which might also explain the leachate from leonardite and peat treatments had higher $\mathrm{pH}$ and concentrations of inorganic carbon.

EC of the solution showed similar variation trend in CK or different treatments (Figure 1c). EC reached the highest value ( $35 \mathrm{mS} / \mathrm{cm}$ or so) at the second elution, and then followed a subsequence decrease. The trend of EC was just opposite to that of $\mathrm{pH}$. In addition, the final mean EC in the solution of $\mathrm{CK}$, peat, biochar and leonardite treatments was 3.34, 2.70, 3.41 and $2.17 \mathrm{mS} / \mathrm{cm}$, respectively. Columns packed with soil treated by biochar had a higher EC final elution while that of the other two humic ameliorators was lower compared with CK.

SAR is suitable for soil solution and irrigation water and related to ESP (exchangeable sodium percentage) on soil clay minerals or exchange complex [30]. SAR is considered as the key concept to explain swelling of clay minerals and the difficulties in reclaiming salt-affected soils. SAR of elution calculated in every leaching event was demonstrated in Figure 1(d). Except SAR in leonardite treatment, the remaining SAR values tended to slowly decline after the soaring rise at the first leaching to indicate the decrease of $\mathrm{Na}^{+}$ in column with the leaching process.

\subsection{Accumulation of ions in soils during and after leaching}

Cumulative $\mathrm{Na}^{+}, \mathrm{K}^{+}, \mathrm{Ca}^{2+}$ and $\mathrm{Mg}^{2+}$ in each leaching was shown in Figure $2 . \mathrm{Na}^{+}$predominantly existed in the leachate to account for more than $75 \%$ of the total cations $\left(\mathrm{Na}^{+}, \mathrm{K}^{+}, \mathrm{Ca}^{2+}\right.$ and $\left.\mathrm{Mg}^{2+}\right)$. Fay and Shi [31] reported that excessive $\mathrm{Na}^{+}$could cause colloidal dispersion and structural damage in saline soils. Therefore, the damage caused by $\mathrm{Na}^{+}$would be probably mitigated when soluble and exchangeable $\mathrm{Na}^{+}$were leached out of soil. At the end of leaching, the accumulative $\mathrm{Na}^{+}$leached from $\mathrm{CK}$, peat, biochar and leonardite treatments reached 30.75, 31.10, 32.69, $30.79 \mathrm{mmol} / \mathrm{column}$, respectively. More $\mathrm{Na}^{+}$was leached from the columns treated by biochar $(p<0.05)$ compared with CK.

$\mathrm{Ca}^{2+}$ concentration in leachate with peat/leonardite treatment was $18.2 \% / 14.1 \%$ higher than that in CK because peat and leonardite contained a certain amount of soluble $\mathrm{Ca}^{2+}$. In addition, humic acid rich in peat and leonardite activated calcium carbonate of the soil to result in more soluble $\mathrm{Ca}^{2+}$ in the leachate.

The accumulative $\mathrm{Mg}^{2+}$ content in the leachate treated by biochar $(6.25 \mathrm{mmol} / \mathrm{column})$ was higher than that of CK (5.72 mmol/column), peat treatment (5.35 mmol/column) and leonardite treatment $(5.32 \mathrm{mmol} / \mathrm{column})$, which might be ascribed to the higher total background $\mathrm{Mg}^{2+}$ content (Table 1). The accumulation of $\mathrm{Mg}^{2+}$ in peat and leonardite treatment was less than that of CK $(p<0.05)$.

Many studies have demonstrated that salt and water movement is the internal mechanism on amendment of salt-affected soil [32,33]. Excessive salt migrated and discharged 

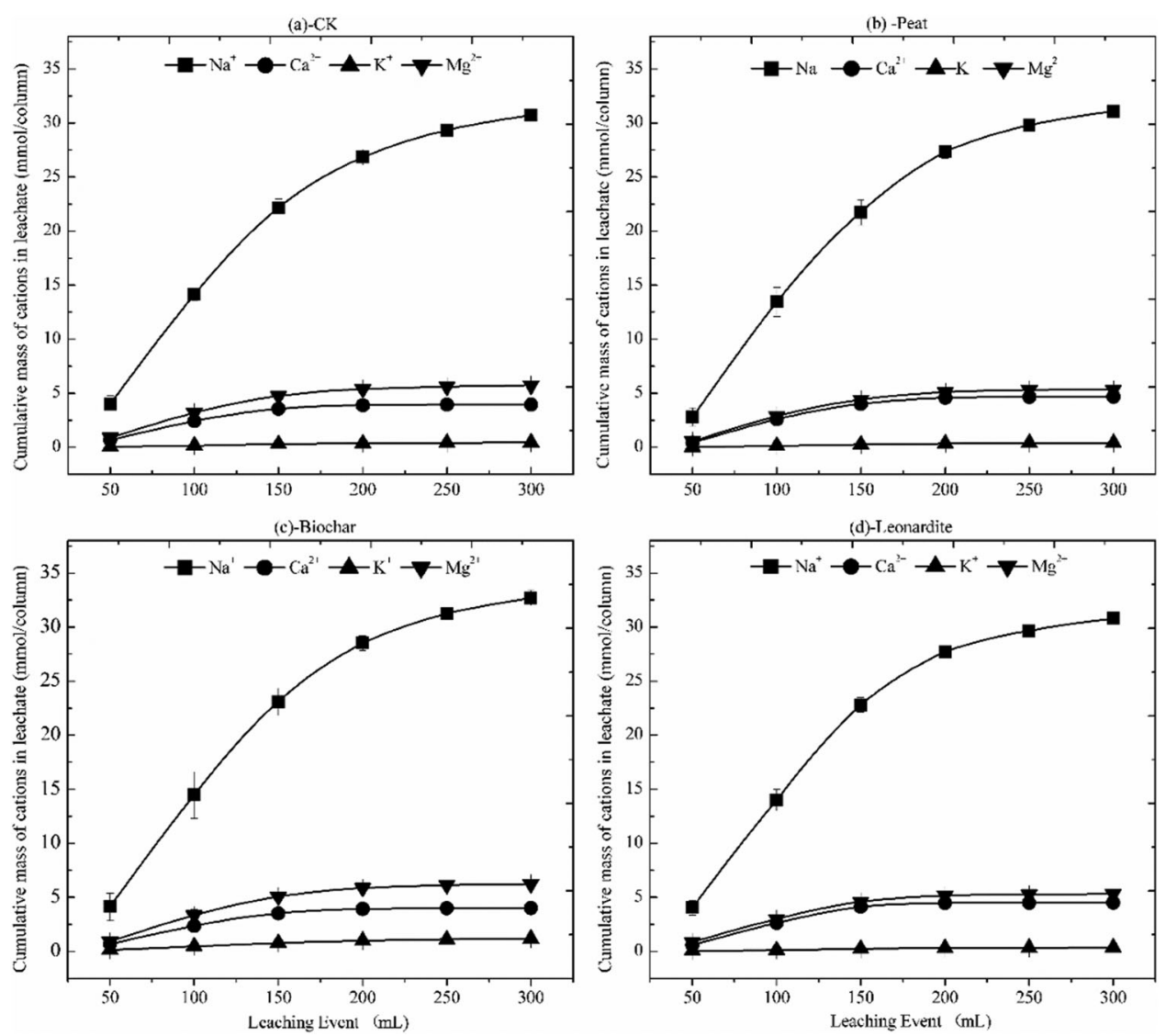

Figure 2. Variation of cumulative cations $\left(\mathrm{Na}^{+}, \mathrm{K}^{+}, \mathrm{Ca}^{2+}\right.$ and $\mathrm{Mg}^{2+}$ ) in leachate (a: cumulative mass of cations in CK; b: cumulative mass of cations in peat treatment; c: cumulative mass of cations in biochar treatment; $d$ : cumulative mass of cations in leonardite treatment).

from soil with effluent is considered as the main contribution to salt reduction [34,35]. After six intermittent leaching, content and composition of cations in the remaining soil took the corresponding change (Figure 3). The content of the most harmful cation $\mathrm{Na}^{+}$in CK and amendment application treatments (peat, biochar and leonardite) decreased by $90.1 \%, 88.5 \%, 90.5 \%$ and $86.57 \%$ at the end of experiment. Biochar contributed to the greatest decline of $\mathrm{Na}^{+}$because of the rigid structure which probably promoted water conductivity to accelerate the discharge of soluble $\mathrm{Na}^{+}$with elution from soil $[2,36]$. In addition, soil columns treated by biochar contained more $\mathrm{K}^{+}(0.26 \mathrm{mmol} / \mathrm{L})$ for the development of crops while $\mathrm{K}^{+}$content in $\mathrm{CK} /$ peat treatment/leonardite treatment was $0.11 / 0.14 / 0.15 \mathrm{mmol} / \mathrm{L}$.

SAR of soil treated by CK, peat, biochar and leonardite reduced by $67.3 \%, 62.9 \%, 70.1 \%$ and $55.0 \%$ (Figure 3e), indicating damage alleviation of cultivated land salinity. SAR results exhibited that the effect of amendment on salt-affected soil varied with the types of ameliorators, which was useful to explain the different effects of organic carbon ameliorators on the improvement of salt-affected soils in the Yellow River Delta. 

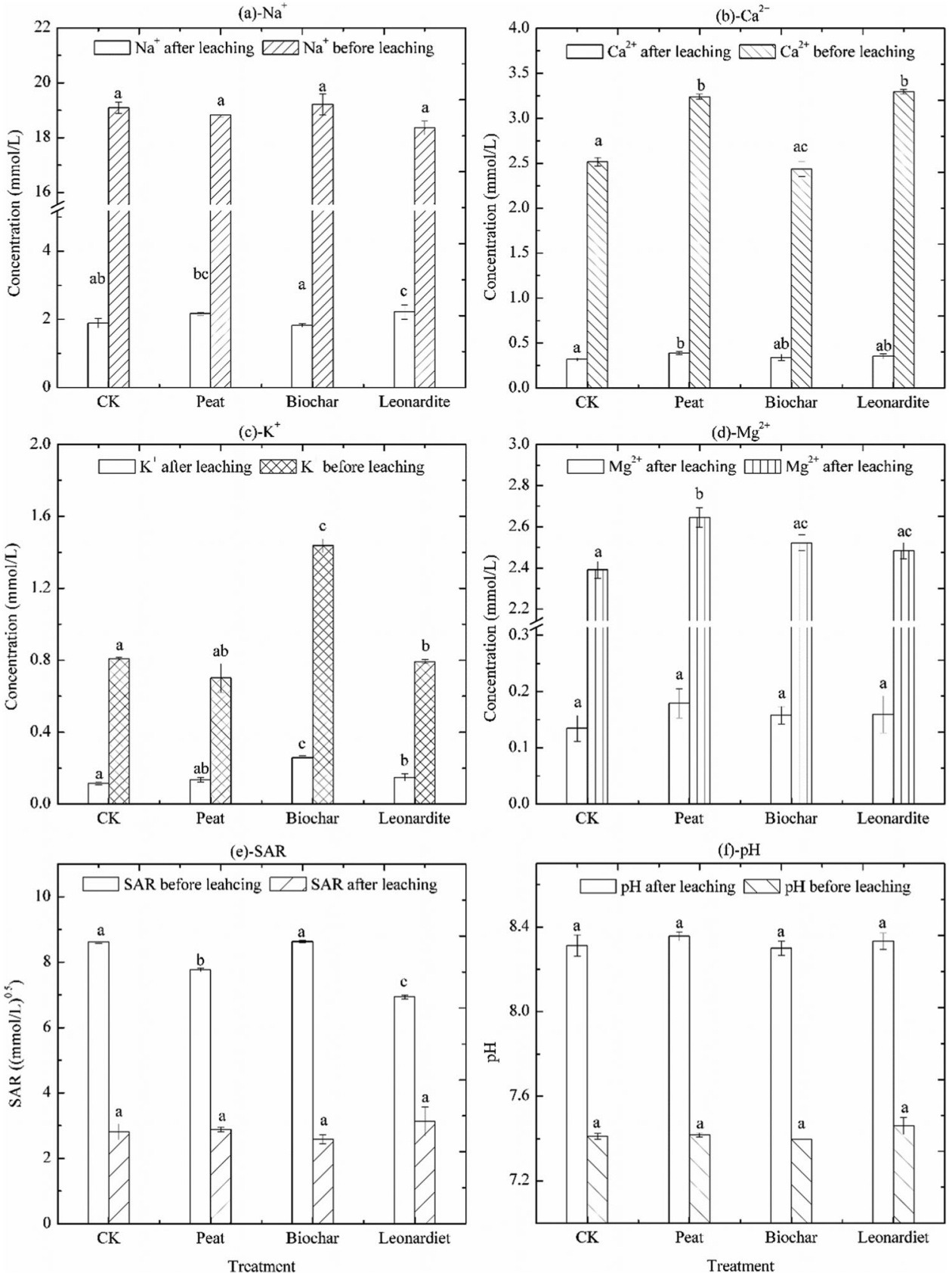

Figure 3. Variation of cation composition, $\mathrm{SAR}$ and $\mathrm{pH}$ compared with the initial. (a: $\mathrm{Na}^{+}$variation of different treatments; $\mathrm{b}$ : $\mathrm{Ca}^{2+}$ variation of inorganic carbon content; $\mathrm{c}$ : $\mathrm{K}^{+}$variation of different treatments; $\mathrm{d}$ : $\mathrm{Mg}^{2+}$ variation of different treatments; e: SAR variation of different treatments; $\mathrm{f}: \mathrm{pH}$ variation of different treatments). 
Soil pH increased by about 1.0 after leaching, and the final pH of CK, peat, biochar and leonardite reached $8.31,8.36,8.30$ and 8.33 respectively. There was no significant difference among various treatments $(p<0.05)$.

\subsection{Accumulation of $\mathbf{N}$ and $\boldsymbol{P}$ during and after leaching}

$\mathrm{NH}_{4}-\mathrm{N}$ and $\mathrm{NO}_{3}-\mathrm{N}$ are believed as the main inorganic nitrogen sources for plants to uptake and utilise [37]. They play a very important impact on plant growth, crop yield and quality. However, the efficiency of nitrogen utilisation was observed to be lower in salt-affected arable land [38]. One of the possible reasons is the serious loss of $\mathrm{NO}_{3}-\mathrm{N}$ companying with eluate due to the high solubility and negative charge [39]. $\mathrm{NO}_{3}-\mathrm{N}$ was dominant in the leachate of each column (Figure 4). Compared with $\mathrm{CK}$, cumulative mass of $\mathrm{NO}_{3}^{-} \mathrm{N}$ in columns treated by organic ameliorators (peat, biochar and leonardite) decreased by $26.9 \%, 12.0 \%$ and $66.4 \%$ respectively, indicating the addition of exogenous carbon ame-

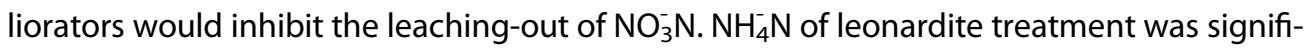
cantly higher than those in other groups because leonardite contained large quantity of $\mathrm{NH}_{4}^{-} \mathrm{N}$ (Table 1). At the end of leaching, the cumulative mass of $\mathrm{NH}_{4}^{-} \mathrm{N}$ of leonardite treatment reached $2.46 \mathrm{mg} /$ column, whereas that of $\mathrm{CK} /$ peat treatment/biochar treatment was $0.41 / 0.45 / 0.39 \mathrm{mg} / \mathrm{column}$. The total soluble nitrogen (including $\mathrm{NO}_{3}^{-} \mathrm{N}^{-}$and $\mathrm{NH}_{4}^{-} \mathrm{N}$ ) in peat/ biochar/leonardite was reduced by $26.2 \% / 11.7 \% / 55.5 \%$ compared with $\mathrm{CK}$, indicating the reduction of nutrient loss and further increase in the efficiency of $\mathrm{N}$ utilisation. The CEC of peat/biochar/leonardite was $75.97 / 134.76 / 53.15 \mathrm{cmol} / \mathrm{kg}$, which was consisted with the reduction ability of N. Generally speaking, CEC comes from the specific carbon functional groups [40] and a higher CEC indicates more existence of hydroxyl and carboxyl functional groups in organic ameliorators [41]. $\mathrm{NH}_{4}^{-} \mathrm{N}$ with positive charge might be physically or chemically adsorbed on these organic carbon groups by the following processes:

$$
\begin{aligned}
\text { Ameliorator }-\mathrm{COOH}+\mathrm{NH}_{4}^{+} & \leftrightarrow \text { Ameliorator }-\mathrm{COONH}_{4}+\mathrm{H}^{+} \\
\text {Ameliorator }-\mathrm{OH}+\mathrm{NH}_{4}^{+} & \leftrightarrow \text { Ameliorator }-\mathrm{ONH}_{4}+\mathrm{H}^{+}
\end{aligned}
$$

It was reported that the leaching of soil $\mathrm{NO}_{3}^{-}$was ascribed to the electrostatic repulsion of negative surface charges which inevitably inhibited the attachment of $\mathrm{NO}_{3}^{-}$to the soil surface [42]. However, slight changes in $\mathrm{pH}$ could make a big distinction on electrostatic repulsion and the repulsion would reduce in acidic environments. In this situation, $\mathrm{NO}_{3}^{-}$ becomes attached to the surface of peat and leonardite due to the acid humic substances. Therefore, peat and leonardite reduced more $\mathrm{NO}_{3}^{-}$loss compared with $\mathrm{CK}$ and biochar treatment and further reduced more total soluble $\mathrm{N}$ since $\mathrm{NO}_{3}^{-}$was dominant in the soil. The result of $\mathrm{NO}_{3}^{-}$retention in biochar was similar to the former study [43], which might be partially explained by porous structure resulting in pore sequestration.

Different from soluble $\mathrm{N}$, phosphate was rapidly released from columns during the leaching process to reach the final accumulative leaching amount of $0.47 / 0.31 / 0.54$ / $0.27 \mathrm{mg} /$ column in CK/peat treatment/biochar treatment/leonardite treatment (Figure 4e). Phosphorus is one of the essential nutrients so that its migration and transformation in soil intensely affect the development of crops. The sorption mechanisms of $\mathrm{PO}_{4}-\mathrm{P}$ are believed to depend on metal ion reactions (such as precipitation and 

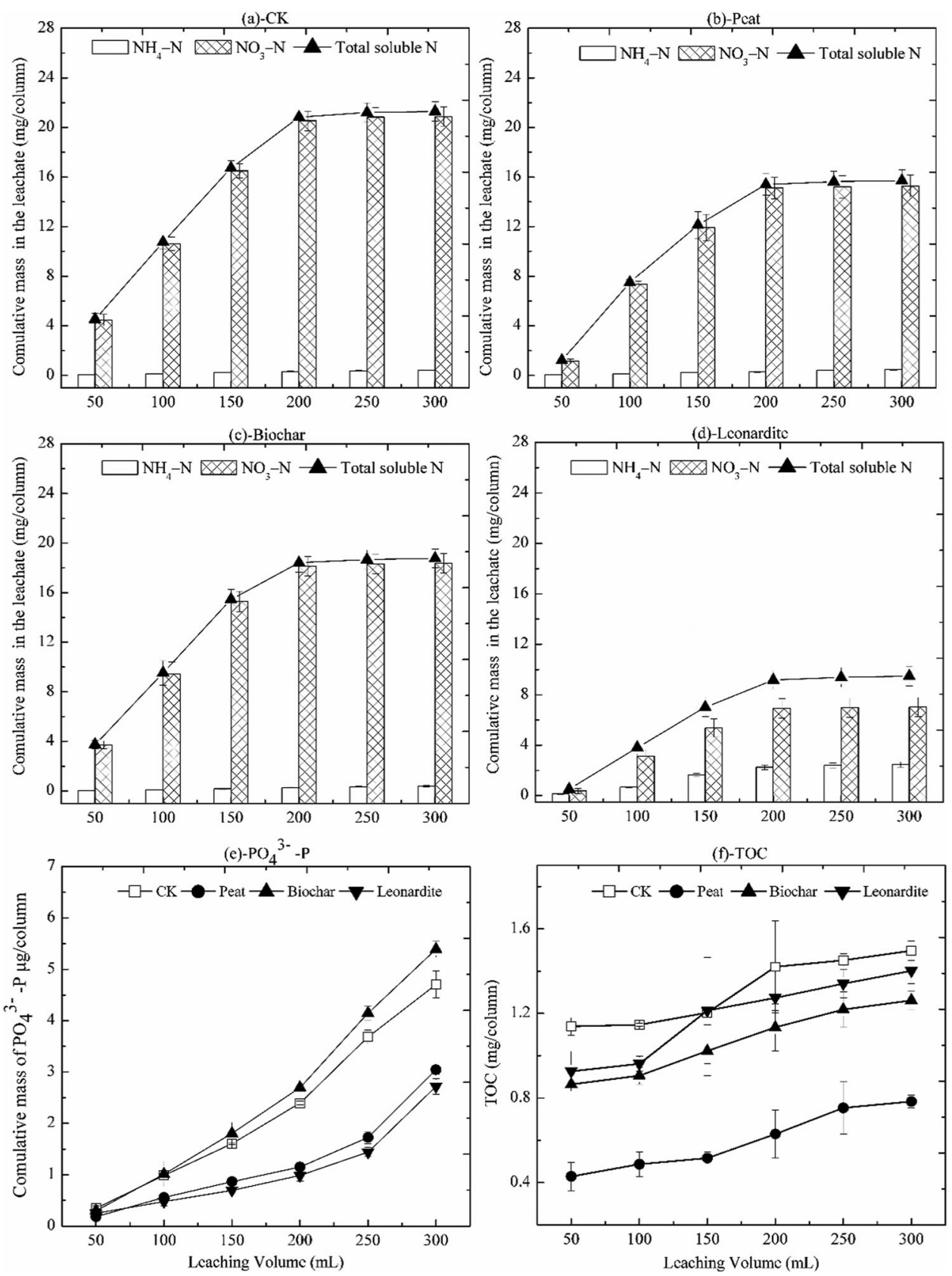

Figure 4. Cumulative mass of soluble $\mathrm{NH}_{4}-\mathrm{N}, \mathrm{NO}_{3}-\mathrm{N}, \mathrm{PO}_{4}^{3-}$ and TOC (a: cumulative mass of soluble $\mathrm{NH}_{4}^{-}$ $\mathrm{N}, \mathrm{NO}_{3}-\mathrm{N}$ in $\mathrm{CK}$; b: cumulative mass of soluble $\mathrm{NH}_{4}-\mathrm{N}, \mathrm{NO}_{3}-\mathrm{N}$ in Peat; c: cumulative mass of soluble $\mathrm{NH}_{4}-\mathrm{N}, \mathrm{NO}_{3}-\mathrm{N}$ in Biochar; d: cumulative mass of soluble $\mathrm{NH}_{4}-\mathrm{N}_{1} \mathrm{NO}_{3}-\mathrm{N}$ in leonardite; e: cumulative mass of $\mathrm{PO}_{4}^{3-}$ by different treatments; f: cumulative mass of TOC by different treatments).

surface deposition) [44]. The cumulative mass of phosphorus in the leachate of biochar treatment increased by $14.6 \%$ compared with CK, though some former research indicated that biochar had no effect or positive effect on retaining $P$ in the soil $[42,45]$. 
The abundant $P$ contained in biochar would attribute to the more loss. The existence of activated $\mathrm{Ca}^{2+}$ in the soil by acid peat and leonardite might lead to simultaneous chemical precipitation and ligand exchange between soil and $\mathrm{PO}_{4}^{3-}$ [46]. Content of $P$ in peat/leonardite treatment decreased by $35.3 \% / 42.2 \%$, much lower than that in biochar treatment, which indicated that humic materials had a better phosphate retention effect. In addition, the cumulative $\mathrm{P}$ loss showed similar variation pattern with the $\mathrm{pH}$ of soil leachates. $\mathrm{P}$ continued to be released from the soil column as the $\mathrm{pH}$ increased through leaching, which was undesirable in the Yellow River Delta from viewpoint of the soil nutrient management.

Dissolved organic carbon (DOC), more mobile and bioavailable part of organic matter in soil, is commonly defined as the organic matter remaining in solution after $0.45 \mu \mathrm{m}$ filtration [47]. The accumulative DOC reached 1.50/0.78/1.26/1.40 mg/column in CK/peat treatment/biochar treatment/leonardite treatment (Figure $4 \mathrm{f}$ ). All organic ameliorators had the ability of preventing the loss of DOM and peat possessed the best performance.

Nutrients in column soils were determined after leaching. The total soluble N was 8.25/ $7.31 / 11.31 / 14.48 \mathrm{mg} / \mathrm{kg}$ in $\mathrm{CK} /$ peat treatment/biochar treatment/leonardite treatment while phosphate was $6.95 / 5.62 / 8.52 / 3.33 \mathrm{mg} / \mathrm{kg}$. The organic carbon content was $4.46 /$ $18.03 / 11.18 / 17.50 \mathrm{mg} / \mathrm{kg}$ in CK/peat treatment/biochar treatment/leonardite treatment. The results showed that organic ameliorators had a positive effect on amending saltaffected soils. Higher retention of nutrients would later lead to a higher crop yield.

\subsection{Expectation}

The peat/biochar/leonardite was used to ameliorate the salt-affected soil in this study. The results indicated that these ameliorators had positive effects on helping the retention of nutrients to significantly promote the levels of soil nutrients. The high CEC and abundant functional groups of ameliorators promoted the amendment potential for soil so that these materials could be used for ameliorating the low yield lands (acid soil, sand land and other soils with low nutrients) and the soils with other anthropogenic impacts such as heavy mental/xenobiotics pollution [48]. Therefore, the three organic materials could play an important role in fighting soil degradation since a significant decrease in soil quality and crop yield has been observed worldwide in the last decades.

Organic ameliorators like peat/biochar/leonardite could foster plant development by providing exogenous organic matters for the soils. The addition of organic ameliorators could improve the nutrient conditions of the soils, increase microbial population and microbial diversity, and then affect ecosystem processes such as primary productivity and nutrient cycling $[49,50]$. Further research on these processes in the future might provide more information on the amendment of salt-affected soils using organic ameliorators.

\section{Conclusion}

Leaching process reduced salt in soil effectively, nearly $90 \%$ of salt was leached out. In addition, the cation composition changed and the SAR of soil column declined consequently. Ameliorators including peat, biochar and leonardite had a positive effect on the amendment of the salt-affected soil. These organic ameliorators not only increased 
soil fertility (N, P, K and organic carbon) but also promoted soil nutrient retention ability and decreased nutrient loss during leaching. Peat and leonardite took advantage on the retention of $\mathrm{N}$, while biochar performed better on supplying of $\mathrm{P}$ and $\mathrm{K}$. All the ameliorators had the ability of $\mathrm{C}$ retention. At the end of leaching, the increase of soil $\mathrm{pH}$ caused by desalination should be paid more attention since increased $\mathrm{pH}$ might accelerate the loss of phosphate in soil.

\section{Acknowledgements}

The authors would like to thank the reviewers for their valuable suggestions and comments on the manuscript.

\section{Disclosure statement}

No potential conflict of interest was reported by the authors.

\section{Funding}

This work was supported by National Natural Science Foundation of China [Grant Number 41671319]; Chinese National Key Research and Development Program [Grant Number 2016YFD0200303]; Taishan Scholar Program of Shandong Province [Grant Number tsqn201812116]; Two-Hundred Talents Plan of Yantai [Grant Number Y739011021]; Science and Technology Service Network Initiative of the Chinese Academy of Sciences [KFJ-STS-QYZX114]; One Hundred Talents Program of Chinese Academy of Sciences [Grant Number Y629041021].

\section{Notes on contributors}

Miss Jie Wang, the Ph.D candidate, major in remediation of salt-affected soils, is affiliated with CAS Key Laboratory of Coastal Environmental Processes and Ecological Remediation, Yantai Institute of Coastal Zone Research (YIC), Chinese Academy of Sciences (CAS).

Dr. Guodong Yuan, professor, major in soil reclamation, is affiliated with CAS Key Laboratory of Coastal Environmental Processes and Ecological Remediation, Yantai Institute of Coastal Zone Research (YIC), Chinese Academy of Sciences (CAS).

Dr. Jian Lu, professor, major in coastal water resource and pollution control, is affiliated with CAS Key Laboratory of Coastal Environmental Processes and Ecological Remediation, Yantai Institute of Coastal Zone Research (YIC), Chinese Academy of Sciences (CAS).

Dr. Jun Wu, professor, major in pollution control, is affiliated with School of Resources and Environmental Engineering, Ludong University, Yantai, People's Republic of China.

Dr. Jing Wei, major in soil remediation, is affiliated with CAS Key Laboratory of Coastal Environmental Processes and Ecological Remediation, Yantai Institute of Coastal Zone Research (YIC), Chinese Academy of Sciences (CAS).

\section{References}

[1] Saifullah, Dahlawi S, Naeem A, et al. Biochar application for the remediation of salt-affected soils: challenges and opportunities. Sci Total Environ. 2018;625:320-335.

[2] Tejada M, Gonzalez JL, García-Martínez AM, et al. Effects of different green manures on soil biological properties and maize yield. Bioresour Technol. 2008;99:1758-1767. 
[3] Mahmoodabadi M, Yazdanpanah N, Sinobas L, et al. Reclamation of calcareous saline sodic soil with different amendments (I): Redistribution of soluble cations within the soil profile. Agric Water Manage. 2013;120:30-38.

[4] Qadir M, Schubert S. Degradation processes and nutrient constraints in sodic soils. Land Degrad Dev. 2002;13:275-294.

[5] Henderson SW, Wege S, Qiu J, et al. Grapevine and Arabidopsis cation-chloride cotransporters localize to the Golgi and trans-Golgi network and indirectly influence long-distance ion transport and plant salt tolerance. Plant Physiol. 2015;169:2215-2229.

[6] Meena MD, Joshi PK, Narjary B, et al. Effects of municipal solid waste compost, rice-straw compost and mineral fertilisers on biological and chemical properties of a saline soil and yields in a mustard-pearl millet cropping system. Soil Res. 2016;54:958-969.

[7] Ding TL, Song J, Guo JR, et al. The cultivation technique for increasing the stalk sugar content of energy plant sweet sorghum in Yellow River delta. Adv Mat Res. 2013;724:437-442.

[8] Hasanuzzaman M, Nahar K, Alam M. Potential use of halophytes to remediate saline soils. Biomed Res Int. 2014;2014:1-12.

[9] Mau Y, Porporato A. Optimal control solutions to sodic soil reclamation. Adv Water Resour. 2016;91:37-45.

[10] Rengasamy P, Tavakoli E, McDonald GK. Exchangeable cations and clay dispersion: net dispersive charge, a new concept for dispersive soil. Eur J Soil Sci. 2016;67:659-665.

[11] Lehmann J. A handful of carbon. Nature. 2007;447:143-144.

[12] Kaleem AM, Ali AA, Raffaella B. Ameliorating effects of biochar derived from poultry manure and white clover residues on soil nutrient status and plant growth promotion greenhouse experiments. PLoS One. 2015;10:e0131592.

[13] Drake JA, Cavagnaro TR, Cunningham SC, et al. Does biochar improve establishment of tree seedlings in saline sodic soils? Land Degrad Dev. 2016;27:52-59.

[14] Pullens JWM, Sottocornola M, Kiely G, et al. Assessment of the water and energy budget in a peatland catchment of the Alps using the process based GEOtop hydrological model. J Hydrol. 2018;563:195-210.

[15] Namkane K, Naksata W, Thiansem S, et al. Utilization of leonardite and coal bottom ash for production of ceramic floor tiles. Environ Earth Sci. 2017;76:628.

[16] Turan MA, Katkat AV, Çelik H. The effects of soil-applied humic substances to the dry weight and mineral nutrient uptake of maize plants under soil-salinity conditions. Not Bot Horti Agrobot Cluj-Napoca. 2011;39:171-177.

[17] Amini S, Ghadiri H, Chen C, et al. Salt-affected soils, reclamation, carbon dynamics, and biochar: a review. J Soils Sediments. 2016;16:939-953.

[18] Mao W, Kang S, Wan Y, et al. Yellow River sediment as a soil amendment for amelioration of saline land in the Yellow River delta. Land Degrad Dev. 2016;27:1595-1602.

[19] Bao SD. Soil agro-chemistrical analysis. 3rd ed Beijing: China Agriculture Press; 2000. p. 187-440. Chinese.

[20] Yeomans JC, Bremner JM. A rapid and precise method for routine determination of organic carbon in soil. Commun Soil Sci Plant Anal. 1988;19:1467-1476.

[21] Gul M, Wakeel A, Saqib M, et al. Effect of NaCl-induced saline sodicity on the interpretation of soil potassium dynamics. Arch Agron Soil Sci. 2016;62:523-532.

[22] Kronzucker HJ, Szczerba MW, Moazami-Goudarzi M, et al. The cytosolic $\mathrm{Na}^{+}: \mathrm{K}^{+}$ratio does not explain salinity-induced growth impairment in barley: a dual-tracer study using ${ }^{42} \mathrm{~K}^{+}$and ${ }^{24} \mathrm{Na}^{+}$. Plant Cell Environ. 2006;29:2228-2237.

[23] Shabala S, Demidchik V, Shabala L, et al. Extracellular $\mathrm{Ca}^{2+}$ ameliorates $\mathrm{NaCl}$-induced $\mathrm{K}^{+}$loss from Arabidopsis root and leaf cells by controlling plasma membrane $\mathrm{K}^{+}$permeable channels. Plant Physiol. 2006;141:1653-1665.

[24] Nan J, Chen X, Wang X, et al. Effects of applying flue gas desulfurization gypsum and humic acid on soil physicochemical properties and rapeseed yield of a saline-sodic cropland in the eastern coastal area of China. J Soils Sediments. 2016;16:38-50. 
[25] Hakim A, Kobayashi M. Aggregation and charge reversal of humic substances in the presence of hydrophobic monovalent counter-ions: effect of hydrophobicity of humic substances. Colloids Surf A Physicochem Eng Asp. 2018;540:1-10.

[26] Belden SE, Schuman GE, Depuit EJ. Salinity and moisture responses in wood residue amended bentonite mine spoil. Soil Sci. 1990;150:874-882.

[27] Sumner ME. Sodic soils: new perspectives. Soil Sci. 1993;31:683-750.

[28] Jurner RC, Brian LM. The pH of calcareous soil. Soil Sci. 1965;82:337-342.

[29] Hinrich LB, Clark JS. Soil chemistry. New York: Wiley; 1985; p. 93-96.

[30] Bourrie G. Swelling clays and salt-affected soils: demixing of $\mathrm{Na} / \mathrm{Ca}$ clays as the rationale for discouraging the use of sodium adsorption ratio (SAR). Eurasian J Soil Sci. 2014;3:245-253.

[31] Fay L, Shi X. Environmental impacts of chemicals for snow and ice control: state of the knowledge. Water Air Soil Pollut. 2012;223:2751-2770.

[32] Wang Q, Huo Z, Zhang L, et al. Impact of saline water irrigation on water use efficiency and soil salt accumulation for spring maize in arid regions of China. Agric Water Manage. 2016;163:125-138.

[33] Chen LJ, Feng Q, Li FR, et al. Simulation of soil water and salt transfer under mulched furrow irrigation with saline water. Geoderma. 2015;241:87-96.

[34] Shaygan M, Reading LP, Baumgartl T. Effect of physical amendments on salt leaching characteristics for reclamation. Geoderma. 2017;292:96-110.

[35] Shaygan M, Baumgartl T, Arnold S, et al. The effect of soil physical amendments on reclamation of a saline-sodic soil: simulation of salt leaching using HYDRUS-1D. Soil Res. 2018;56:829-845.

[36] Whalley WR, Clark LJ, Gowing DJG, et al. Does soil strength play a role in wheat yield losses caused by soil drying? Plant Soil. 2006;280:279-290.

[37] Xing S, Wang J, Zhou Y, et al. Effects of $\mathrm{NH}_{4}-\mathrm{N} / \mathrm{NO}_{3}-\mathrm{N}$ ratios on photosynthetic characteristics, dry matter yield and nitrate concentration of spinach. Exp Agric. 2015;51:151-160.

[38] Sun JX, Kang YH, Wan SQ. Effects of an imbedded gravel-sand layer on reclamation of coastal saline soils under drip irrigation and on plant growth. Agric Water Manage. 2013;123:12-19.

[39] Dendooven L, Alcántara-Hernández RJ, Valenzuela-Encinas C, et al. Dynamics of carbon and nitrogen in an extreme alkaline saline soil: A review. Soil Biol Biochem. 2010;42:865-877.

[40] Boyer A, Ning P, Killey D, et al. Strontium adsorption and desorption in wetlands: role of organic matter functional groups and environmental implications. Water Res. 2018;133:27-36.

[41] Tan KH. Humic matter in soil and the environment: principles and controversies. Boca Raton: CRC Press; 2014.

[42] Zheng $H$, Wang $Z$, Deng $X$, et al. Characteristics and nutrient values of biochars produced from giant reed at different temperatures. Bioresour Technol. 2013;130:463-471.

[43] Yao Y, Gao B, Zhang M, et al. Effect of biochar amendment on sorption and leaching of nitrate, ammonium, and phosphate in a sandy soil. Chemosphere. 2012;89:1467-1471.

[44] Wang Z, Guo H, Shen F, et al. Biochar produced from oak sawdust by lanthanum (La)-involved pyrolysis for adsorption of ammonium $\left(\mathrm{NH}_{4}^{+}\right)$, nitrate $\left(\mathrm{NO}_{3}^{-}\right)$, and phosphate $\left(\mathrm{PO}_{4}^{3-}\right)$. Chemosphere. 2015;119:646e653.

[45] Yuan H, Lu T, Wang Y, et al. Sewage sludge biochar: nutrient composition and its effect on the leaching of soil nutrients. Geoderma. 2016;267:17-23.

[46] Xue Y, Hou H, Zhu S. Characteristics and mechanisms of phosphate adsorption onto basic oxygen furnace slag. J Hazard Mater. 2009;162:973e980.

[47] Smebye A, Alling V, Vogt RD, et al. Biochar amendment to soil changes dissolved organic matter content and composition. Chemosphere. 2016;142:100-105.

[48] Bonanomi G, De Filippis F, Cesarano G, et al. Organic farming induces changes in soil microbiota that affect agro-ecosystem functions. Soil Biol Biochem. 2016;103:327-336.

[49] Sumner ME. Sodic soils: new perspectives. In: Naidu R, Sumner ME, Rengasamy P, editor. Australian sodic soils: distribution, properties, and management. Melbourne: CSIRO; 1995. p. 1-34.

[50] Bastida F, Selevsek N, Torres IF, et al. Soil restoration with organic amendments: linking cellular functionality and ecosystem processes. Sci Rep. 2015;5:15550. 